\title{
Dari JI ke ISIS: Pemikiran Strategis dan Taktis Gerakan Terorisme di Asia Tenggara
}

\author{
Badrus Sholeh \\ Program Studi Ilmu Hubungan Internasional, Universitas Islam Negeri Syarif Hidayatullah Jakarta \\ Jalan Kertamukti no. 5 Ciputat, Tangerang 15419, Indonesia \\ badrus.sholeh@uinjkt.ac.id \\ Diserahkan: 20 November 2016, diterima: 27 Januari 2017
}

\begin{abstract}
This article examines the transformation of terrorist groups in the Southeast Asia, ranging from from Jama'ah Islamiyah (JI) to the Islamic State of Iraq and Syria (ISIS). It examines the movements and thoughts of the combatant leaders who fought in the battlefields and wrote books, blogging and social media to defend their jihad argument and strategically used by young generation and current terrorist groups, affiliated to JI and ISIS to recruit, consolidate and fight against so-called infidel governments of Southeast Asia and global coalition. The strategy and tactic of ISIS in the Southeast Asia vary from the networking of Syria-Iraq and Southeast Asia through Katibah Nusantara in Syria-Iraq and the home-grown terrorist networks in Indonesia, Malaysia and the Philippines. The challenge for state and civil society in Southeast Asia is greater given the current terrorist groups' movement which mostly recruit the youth and taking advantages from the online media, blogging and social media. It challenged the security threats and counter narratives developed state and civil society.

Keywords: Jama'ah Islamiyah, ISIS, Terrorism, Southeast Asia
\end{abstract}

\begin{abstract}
Abstrak
Artikel ini membahas transformasi kelompok teroris di Asia Tenggara dari Jama'ah Islamiyah (JI) ke Negara Islam Irak dan Suriah (NIIS). Artikel ini membahas gerakan dan pemikiran komandan dan tokoh kombatan yang tidak hanya terlibat dalam pertarungan tetapi juga menulis buku, blog, media sosial untuk mempertahankan argumen Jihad mereka dan secara strategis digunakan oleh generasi muda dan kelompok teroris saat ini, yang berafiliasi dengan JI dan ISIS untuk merekrut, melakukan konsolidasi dan bertarung melawan pemerintah dan koalisi global thoghut. Strategi dan taktik ISIS Asia Tenggara bekerja dalam jaringan Suriah-Irak-Asia Tenggara melalui Katibah Nusantara di Suriah dan Irak dan jaringan teroris dalam negeri di Indonesia, Malaysia dan Filipina. Tantangan negara dan masyarakat sipil di Asia Tenggara lebih besar khususnya setelah bagaimana kelompok teroris merekrut kebanyakan pada generasi muda dan mengambil manfaat besar pada media online, blog dan media sosial. Hal ini menjadi tantangan bagi ancaman keamanan dan kontra narasi yang dikembangkan oleh pemerintah dan masyarakat sipil.
\end{abstract}

Kata kunci: Jama'ah Islamiyah, ISIS, Terorisme, Asia Tenggara

\section{PENDAHULUAN}

John Horgan menyatakan bahwa terjadi perubahan seorang atau sekelompok teroris dari orientasi kekerasan menuju non kekerasan karena transisi politik. Pada tahap berbeda mereka bisa kembali menjadi lebih radikal pada saat munculnya pulling factor solidaritas global atas adanya diskriminasi atau sebaliknya kekuatan kelompok transnasional dunia yang menguatkan ide, gagasan dan gerakan teroris di wilayah lain (Horgan, 2008). Radikalisme dan ektrimisme terjadi pada semua agama dan kelompok nasionalis. Gerakan teroris Aum Shinrikyo, didirikan pada 1984, dan melancarkan serangan mematikan gas sarin di subway Tokyo pada 1995 adalah kelompok ekstrimis Budha. Demikian juga di Myanmar, sekelompok pendeta Budha memimpin penyerangan atas warga Muslim di provinsi Rakhine. Sidney Jones menyatakan "I think it's important to underscore that not all extremism is islamist. You only have to look in Myanmar 
to see extremism in another form" (Jones, 2015).

Deklarasi Abu Bakar Al Baghdadi tentu saja menjadi salah satu faktor bagaimana "janji" negara Islam dan Khilafah Islamiyah di Suriah dan Irak menarik perhatian dari individu dan kelompok jihadis seluruh dunia. Hingga pertengahan 2015, lebih dari 30.000 kombatan jihadis berasal dari sekitar 90 negara asing datang ke Suriah dan Irak, termasuk seribu diantaranya dari Asia Tenggara. Pada 26 September 2014, para kombatan Asia Tenggara membentuk organisasi Katibah Nusantara Lid Daulah Islamiyah (selanjutnya disebut Katibah Nusantara-KN) yang dibentuk oleh sekitar 500-700 kombatan dari Indonesia, 200 dari Malaysia, dan sisanya dari Filipina dan Singapura (Singh, 2015). KN berpusat di Al-Shadadi, Provinsi Haraka Suriah. Komandan KN adalah Abu Ibrahim al-Indunisiy a.k.a Bahrumsyah. Katibah Nusantara memberi pengaruh kuat melalui penerbitan dan publikasi media online, blogging, youtube dan media sosial bagi pergerakan dan serangan terorisme di Asia Tenggara. Bahrun Naim, salah satu komandan KN secara rutin menerbitkan manual pembuatan bom, serangan gerilya kota, manual senjata biologis dan kimia, hacking, strategi propaganda dan rekrutmen, hingga lebih taktis cara serangan yang efektif. Beberapa kali web pribadi dan akun Facebook Bahrun Naim di blok tetapi terus berhasil terbit lagi, dan selalu mendapat ratusan komentar dan sambutan. Naim telah menggeser pola tulisan buku dan pamflet yang dulu digunakan oleh Jama'ah Islamiyah dalam rekrutmen dan propaganda dengan pola baru yang lebih cool dan modern melalui tulisan lebih singkat dan efektif. Beberapa serangan lonewolf yang dilakukan pada 2016 oleh ISIS di Asia Tenggara dilakukan melalui guidance jarak jauh lewat media sosial dan online langsung dari Suriah.

Gerakan teroris berkembang melalui peran aktoraktor intelektual yang memberi landasan pemikiran strategis dan taktis dalam pergerakan teroris. Beberapa peristiwa pengeboman dan serangan terorisme di Indonesia dilakukan atas stimulasi dan pengaruh guidance dari para komandan teroris baik dilakukan secara tertutup melalui pengajian maupun terbuka melalui penerbitan, publikasi dan tulisan pendek di media online, blogging dan sosial media. Penyerangan Thamrin Jakarta pada Januari 2016 adalah diantara aksi yang mendapat pengaruh kuat dari posting tulisan dari para komandan para pelaku. Adalah Bahrun Naim dan Aman Abdurrahman, dua tokoh ISIS Indonesia yang memengaruhi para pelaku dalam menjalankan aksi terorismenya. Para pelaku terpengaruh pada pemikiran Jihad, dan menjalankan instruksi yang dipublikasikan melalui media online dan media sosial. Pemikiran elit jihadis dan teroris berpengaruh kuat atas perkembangan dan pergerakan teroris. Kontra narasi dilakukan oleh pemerintah dan masyarakat sipil untuk membendung derasnya arus informasi radikal yang secara progresif dilakukan oleh ISIS. Pada tahap lebih kuat dan mengakar Jama'ah Islamiyah (JI) dan kelompok yang berafiliasi dengan Al-Qaidah telah melakukan pengaruh intelektual dan pemikiran ideologi jihadis melalui lembaga pendidikan, publikasi dan media yang lebih lama mereka kembangkan. Sekitar tiga puluh sekolah yang berafiliasi dengan JI yang tersebar di Jawa Timur, Jawa Tengah, Jawa Barat, Jabodetabek, dan Indonesia Timur menjadi breeding grown efektif yang melahirkan generasi penerus jihadis (Magouirk dan Atran, 2008). Diantara mereka kemudian berafiliasi dengan ISIS, bahkan telah menjadi pelaku bom bunuh diri di Suriah. Wildan Mukhollad (lahir 6 Januari 1995) adalah salah satu mantan siswa di Pesantren Al-Islam Lamongan yang mendaftarkan sebagai sukarelawan bom bunuh diri ISIS di Suriah dan Irak. Wildan dipaksa orang tuanya untuk pindah dari Al-Islam Lamongan ke Al Azhar Mesir sekitar 2011 dengan tujuan untuk mengurangi ideologi jihadis yang dipelajari oleh Wildan di Pesantren Al-Islam, tetapi Wildan menunjukkan respon lebih keras (Asad, 2014). Ketika ke Mesir, Wildan memiliki pemikiran dan peran lebih radikal dengan meninggalkan bangku sekolah dan bergabung dalam medan perang di Suriah melawan rejim Bashar Al-Asad. Pada pertengahan 2012 Wildan berangkat ke Aleppo bergabung dengan kelompok jihadis. Ketika Al-Baghdadi mendeklarasikan diri menjadi Khalifah, Wildan termasuk diantara yang bergabung. Pada awal 
Februari 2014 menyeberang ke Irak untuk menjadi pelaku bom bunuh diri ISIS. Di Irak, Wildan dikenal dengan nama Abu Bakar Al-Muhajir Al-Wildan Mukhollad bin Lasmin (Damanik, 2014).

Aksi strategis dan taktis JI dan ISIS di Asia Tenggara dilakukan melalui beberapa hal. Pertama, konsolidasi komunitas Jihadis menjadi strategi utama. Konsolidasi ini dilakukan pada lima sampai sepuluh tahun pertama setelah organisasi teroris berdiri. JI berdiri pada 1993 di Kuala Lumpur, dan Afghan veteran kembali ke Indonesia dan Asia Tenggara melalukan konsolidasi dan gerakan strategis melalui madrasah, sekolah, majelis taklim dan pelatihan fisik lainnya. Menurut Farihin a.k.a Yasir antara 1993 hingga 1998 adalah periode penting bagi JI untuk "mengumpulkan kekuatan dan menjaga kualitas keilmuan dan kemiliteran melalui pendidikan formal, mengajarkan di madrasah dan pesantren serta pelatihan fisik kepada kelompok pemuda di beberapa organisasi Jihad lokal" (Farihin, 2015). Kedua, praktik jihad terutama sebagai respon atas konflik dan perang yang mendorong JI dan ISIS untuk "menjawab panggilan Jihad" akibat banyaknya Muslim yang terbunuh di medan konflik dan perang. JI mengirim pasukan Jihad secara resmi setelah terjadinya konflik Ambon dan Poso pada 1999. Mereka memiliki waktu dan kapasitas yang lebih memadahi setelah sekitar sepuluh tahun berlatih di Afghanistan dan Mindanao, serta melakukan konsolidasi komunitas dan keluarga JI. Gerakan taktis dimulai dengan membuka pelatihan paramiliter di Ambon dan Poso antara 1999 dan 2001, dan melakukan aksi-aksi pemboman dan penyerangan pada basis-basis dan target yang mereka anggap sebagai "musuh Islam," misalnya penyerangan desa Kristen dan gereja di Ambon dan Poso, pemboman gereja di Jawa Timur dan pemboman Sari Club dan Paddys Club di Bali pada Oktober 2002. Sementara ISIS memiliki pola berbeda. Mereka tidak mensyaratkan sukarelawan Jihad untuk menyiapkan diri secara kuat sebelum berangkat untuk ikut perang di Suriah. ISIS memiliki gerakan taktis yang berbeda dengan JI. ISIS memanfaatkan media sosial untuk rekrutmen, konsolidasi, mobilisasi dan aksi Jihad antara 2013 dan 2015, lebih dari 500 sukarelawan Indonesia bergabung dengan ISIS di Suriah dan Irak (Sholeh, 2016). Ketiga, gerakan strategis dan taktis JI dan ISIS didukung oleh pemikiran Jihad, publikasi dan perdebatan yang didominasi oleh elit intelektual jihadis di Asia Tenggara khususnya Indonesia.

Derasnya publikasi dan perdebatan ini memengaruhi radikalisasi Muslim di Asia Tenggara karena penonton dan pembaca karya tulis baik melalui penerbitan jaringan jihadis maupun melaui media online mendapat komunitas pembaca yang banyak di Malaysia dan beberapa negara di Asia Tenggara.

Al-Aqwam penerbit buku-buku Al-Qaidah dan JI sering menjual buku-bukunya hingga negeri jiran Malaysia. Demikian juga blog pribadi Aman Abdurrahman yang memuat artikel dan buku-buku terjemahan dan pemikiran Aman dibaca secara serius di madrasah dan majelis taklim di Indonesia dan Asia Tenggara. Imam Samudra juga menulis beberapa buku yang menegaskan pandangan dia atas perannya dalam aksi bom Bali 2002. Bahkan Samudra memasukkan bab khusus bagaimana internet menjadi media penting dalam aksi terorisme. Dalam konteks ini Samudra melihat peluang hacking, fa'i dan propaganda melawan Barat menjadi metode strategis dan taktis melalui internet. Gagasan Samudra menginspirasi jihadis muda Indonesia yang kemudian berperan besar dalam propaganda dan aksi terorisme yang dikendalikan oleh ISIS di Indonesia dan Asia Tenggara. Bahrun Naim memberi instruksi bagaimana menciptakan sel jihad agar terhindar dari tracking Densus 88, juga berhasil mengajak ratusan sukarelawan jihad melalui Facebook dan Telegram yang dikelola oleh komunitas ISIS.

Jauh sebelum Aman Abdurrahman menulis buku Jihad, Abu Bakar Ba'asyir dan para pelaku Bom Bali juga beberapa kali menulis buku Jihad yang menyerukan pentingnya Jihad bagi perjuangan Ummat Islam dari tekanan internasional dan melakukan kritik atas pemerintah dan koalisi Barat. Jihadis Indonesia yang aktif menulis dari penjara terkait aksi terorisme terinspirasi dari para penulis terkenal di dunia Arab. Ba'asyir menyinggung Ibnu Taimiyah dan Sayyid Qutub sebagai figur mujahidin yang tetap menjaga 
keagamaan dan berdakwah melalui tulisan meski mendapat tekanan penguasa. Ba'asyir menyebut mereka sebagai Ulama Robbaniyyin. Ba'asyir memberi endorsement atas konsistensi Aman Abdurrahman dalam menulis saat di penjara dengan menyebut Aman sebagai "seorang alim muda yang konsekuen yang menegakkan kemurnian tauhid. Sebagaimana ulama robbaniyyin Al-Ustadz Abu Sulaiman Aman

Abdurrohman juga berusaha memanfaatkan rahmat Allah dalam penjara yang ditimpakan oleh thaghut penguasa negeri ini dengan menulis risalah-risalah tauhid dan risalah dakwah lainnya" (Ba'asyir, 2013).

Publikasi Jihadis memiliki setidaknya tiga tujuan. Pertama, argumentasi atas tindakan mereka dalam melakukan aksi pemboman dengan legitimasi agama. Bahkan Imam Samudra menulis khusus membantah buku penulis lain (Nasir Abbas) dan menegaskan posisi dia sebelum eksekusi dilakukan. Kedua, industri jihadis tumbuh dengan baik dan memberi manfaat ekonomis bagi terpidana teroris dan keluarganya. Buku Imam Samudra cetak lebih dari empat puluh ribu eksemplar dan masih juga habis di pasaran. Ketiga, tulisan memberi inspirasi bagi siswa dan pemuda untuk melanjutkan tradisi Jihad. Dalam banyak kesempatan tulisan menjadi acuan penting dalam rekrutmen dan pelatihan jihad. Buku dan tulisan online Aman Abdurrahman menginspirasi banyak individu dan kelompok yang melakukan serangan independen (lone wolf) didukung dengan penjelasan manual yang dalam dua tahun terakhir dilakukan oleh para pendukung dan simpatisan ISIS. Bahrunnaim diantaranya membuat facebook dan personal blog untuk mendorong Muslim di Asia Tenggara, khususnya yang berbahasa Melayu untuk melakukan aksi terorisme melawan pemerintah dan koalisi internasional. Selfradicalisation ini menjadi perhatian ASEAN Summit pada September 2016, ketika hampir semua pemimpin negara sepakat ancaman terorisme telah menjadi tantangan tidak hanya negara-negara anggota ASEAN tetapi juga dunia. Aksi individu menjadi lebih sulit diprediksi oleh intelejen negara dan pihak keamanan untuk mengantisipasi serangan. ISIS pada edisi publikasi Juni 2016 menyerukan serakan setiap sukarelawan jihad secara personal dan kelompok kecil untuk menyerang dengan senjata yang dimiliki oleh jihadis. Serangan tidak harus besar dan monumental tetapi bisa secara simbolik terhadap anggota kepolisian dan keamanan. Pada 2016, Malaysia, Indonesia dan Filipina Selatan mengalami serangan melalui gerakan individu yang digerakkan oleh ISIS melalui peran dan pengaruh elit jihadis asal Asia Tenggara Katibah Nusantara di Suriah.

Buku Dakwah dan Jihad Abu Bakar Ba'asyir yang ditulis pada 2003 menjadi salah satu buku awal yang ditulis jihadis pasca Bom Bali pada Oktober 2002. Dalam menulis pengantar bukunya Ba'asyir ketika dipenjara terkait aksi Bom Bali menyatakan,

"Dalam mengisi hidup ini, para ulama memberi nasehat yang singkat kalimatnya namun padat isinya 'Hidup mulia atau mati syahid'. Hidup mulia artinya hidup yang diatur dengan syari'at Islam secara kaffah, atau hidup yang dipenuhi dengan perjuangan menegakkan Syari'at Islam, kemudian dengan sabar rela menanggung segala resikonya. Sedangkan mati syahid ialah mati terbunuh oleh musuh Islam dalam jihad fi sabilillah, atau dibunuh oleh penguasa dhalim karena berani menyuarakan kebenaran (Ba'asyir, 2003: 5).

Artikel ini akan membahas strategi dan taktik aksi dan pemikiran kelompok teroris baik Jama'ah Islamiyah maupun ISIS di Asia Tenggara. Artikel ini berasal dari wawancara mendalam dengan teroris di penjara dan luar penjara, serta kajian dokumen terkait dengan perkembangan terorisme di Asia Tenggara. Argumen artikel ini adalah bahwa pemikiran elit kombatan baik pada level global maupun regional memengaruhi kuat dalam pola rekrutmen dan perkembangan terorisme. Tantangan serius terhadap fenomena ini adalah tidak hanya taktik tindakan dalam menghentikan aksi dan rencana serangan teror tetapi lebih penting lagi dalam kontra narasi yang membutuhkan kerjasama yang kuat antara pemerintah dan masyarakat sipil. 


\section{PEMBAHASAN}

\section{PERDEBATAN PASCA BOM BALI}

Pasca bom Bali 2002 terjadi perdebatan melalui publikasi buku yang dilakukan oleh para elit JI dan pelaku Bom Bali. Tradisi menulis ini kemudian berlanjut ke elit ISIS yang memengaruhi pergerakan dan aksi terorisme di Asia Tenggara antara 2013 hingga 2015.

Buku dan artikel Jihadis berlanjut dari Ba'asyir ke Aman Abdurrahman. Sementara Abu Bakar Ba'asyir menulis buku-buku serial Tazkirah dengan dukungan organisasi Jama'ah Ansharut Tauhid, sebagai pelengkap dari tulisan Ba'asyir Dakwah dan Jihad. Buku Tazkirah tidak dicetak secara resmi dan difotokopi untuk didiskusikan dibanyak forum jihad di seluruh Indonesia melalui JAT. Demikian juga, buku Jihad Aman didiskusikan oleh kelompok Tauhid wal Jihad serta Jama'ah Ansharul Khilafah sebagai bagian dari instrumen dakwah dan soliditas kelompok dan keluarga Mujahidin.

Buku Seri Materi Tauhid karya Abu Sulaiman Aman Abdurrahman yang bisa diunduh di millahibrahim.wordpress.com terbagi menjadi beberapa bagian pokok. Pertama, prinsip ketauhidan melalui pemaknaan Thaghut dan bagaimana kewajiban Muslim untuk beriman kepada Allah dan kufur terhadap thaghut. Kedua, kritik atas praktik demokrasi sebagai bagian dari tradisi Thaghut. Termasuk didalamnya status hukum nasional. Ketiga, penegasan Aman atas penolakan keta'atan terhadap pemerintah Indonesia, juga bagaimana Muslim bekerja sebagai PNS dan bekerja di perusahaan pemerintah. Dalam melihat status pegawai pemerintah Aman Abdurrahman menyatakan "setiap pekerjaan yang merupakan pembuatan hukum, pemutusan dengan hukum buatan, pembelaan kepada thaghut atau sistemnya, mengikuti atau menyetujui sistem thaghut, ada syarat sumpah atau janji setia kepada thaghut atau sistemnya, maka semua ini adalah kekafiran" (Abdurrahman, 2015: 161).

Karya Aman bukanlah sesuatu yang baru dalam penulisan jihadis. Tulisan karya bomber Bali menjadi pioneer atas publikasi aktivis Jihad, terutama menempatkan publikasi pada perusahaan penerbitan yang dikelola oleh kelompok jihadis. Publikasi didominasi oleh jaringan Alumni Afghanistan dan Alumni Ngruki. Jazera (Al Aqwam Group) Solo dan Arrahmah Media Jakarta menjadi penerbit yang ikut memengaruhi semangat penerbit-penerbit kelompok radikal lain. Dengan menerbitkan karya para Jihadis, mereka menunjukkan positioning yang berbeda dengan umumnya penerbit Islam. M. Fachry, Pemred Arrahmah Media menyatakan,

"Termasuk buku 'Trio Syuhada', tiga orang yang menurut mereka melakukan suatu kebaikan. Tapi dinista oleh banyak orang dan dianggap mereka melakukan keburukan. Apa alasan dari mereka dan apa alasan mereka ini kita angkat. Ini yang kemudian akhirnya arRahmah media dikenal sebagai penerbit yang punya ciri khas. Walaupun mungkin kecil dan baru berkembang tapi sudah bisa membetot perhatian. Karena tadi positioning-nya alhamdulillah kita anggap tepat. Hikmahnya di situ" (Fachry, 2010).

Arrahmah Media juga memiliki alasan khusus untuk menerbitkan buku Trio Syuhada dan kelompok Jihad lainnya. Fachry melihat bahwa,

"Karena orang kebanyakan menganggap tiga orang ini adalah berbuat kerusakan, teroris. Nah, kita perlu cek dan ricek, kita perlu tabayyun kepada pelakunya sendiri. Betul enggak Anda melakukan teror sebagaimana yang disampaikan. Apa sih pandangan-pandangan Anda. Kemudian mereka juga ternyata merasa perlu untuk membuat bantahan, membuat klarifikasi kepada umat. Dan dia mencari juga media mana yang mau menyalurkan aspirasi dan suara mereka. Mereka ketemu dengan kita. Kemudian, sebelum mereka ketemu mereka sudah melihat kemungkinan media mana yang fokus dan concern dengan masalah ini. Melihat ar-Rahmah media, mereka setuju mau diterbitkan. Alhamdulillah jadi menerbitkan buku tersebut. Karena kan mereka memiliki bantahan dan klarifikasi yang selama ini sudah dituduhkan kepada mereka. Jadi mereka sudah terstigma sebagai teroris. Itu yang kemudian kita sampaikan. Sebenarnya rencana mengangkat lagi kisah-kisah yang dianggap teroris ini yang sebenarnya mereka menganggap 
sebagai mujahidin kita masih banyak memiliki

keinginan" (Fachry, 2010).

\section{PENGARUH KOMBATAN INTERNASIONAL}

Abu Bakar Ba'asyir dan Aman Abdurrahman banyak dipengaruhi oleh teks-teks karya Ibnu Taimiyah dan Sayyid Qutb. Juga risalah yang ditulis oleh Aiman $\mathrm{Az}$ Zawahiri memengaruhi generasi jihadis Indonesia dan dunia. Aman Abdurrahman dianggap memiliki pengaruh kuat atas pergeseran Abu Bakar Ba'asyir yang kemudian berbai'at kepada Abu Bakar Al Baghdadi. Ba'asyir membaca banyak buku Aman dan memberi pengantar. Pertukaran tulisan di penjara Nusa Kambangan saling memengaruhi tahanan teroris (Sholeh, 2013). Aman Abdurrahman alias Oman Rochman alias Abu Sulaiman Al-Arkhabily memiliki julukan Singa Tauhid, lahir di Cimalaka-Sumedang, 5 Januari 1972. Penjara di Indonesia tidak memiliki cukup regulasi dalam mencegah peredaran tulisan dan diskusi karya jihadis di penjara-penjara. Tahanan teroris yang bergabung dengan ISIS secara rutin mendiskusikan buku dan artikel Aman dan Ba'asyir, selain Dabiq yang bebas diunduh melalui smartphone (Bambang, 2016). Aman dipengaruhi oleh Abu Muhammad Al Maqdisi dan Abu Musab Az Zarqowi dalam banyak tulisan, pidato dan gerakan jihadnya. Karena itu ketika ISIS muncul Aman begitu akrab dengan jargon dan semangat Jihadi takfiri yang sebelumnya digagas dan dikembangkan oleh $\mathrm{Al}$ Maqdisi dan Az Zarqawi.

Perubahan sikap seseorang untuk bergabung dalam kelompok Jihad dan melakukan aksi teror banyak diilhami oleh tokoh-tokoh dan penulis Jihadis. Imam Samudra yang mempelopori awal tulisan anggota Jama'ah Islamiah sejak 2004, Aku Melawan Teroris (AMT), yang terbit ulang beberapa kali (tiga kali berturut-turut dalam tiga bulan: September, Oktober dan November 2004) dengan oplah lebih dari 50 ribu eksemplar. Menurut editornya, Bambang Sukirno yang juga direktur Al Aqwam, buku ini semula berasal dari "Catatan Harian" Imam Samudra. Dia mengusulkan judulnya menjadi AMT, dengan alasan "judul itu lebih mencerminkan isi buku dan niat aksi yang mereka
lakukan”(Sukirno, 2004).

Penerbit Jazera yang berbasis di Solo mendapatkan banyak keuntungan dari penerbitan ini, terutama menjadi salah satu penerbit yang dikenal masyarakat lebih luas. Setelah penerbitan AMT, Jazera sub bagian dari Yayasan Al Aqwam, terus menerbitkan buku-buku para Mujahidin Timur Tengah dengan mengandalkan terjemahan. Menurut mereka penulis Indonesia sangat terbatas jumlahnya, sementara permintaan pasar cukup tinggi. Sejak 2004, banyak muncul penerbitan yang dikelola secara mandiri dengan manajemen kecilmenengah. Mereka tidak akan bersaing dengan penerbit besar seperti Gramedia dan Mizan. Mereka mengandalkan kelompok pembaca tertentu baik melalui pengajian (majelis taklim), bedah buku-buku Islam dan agen-agen lepas yang membeli langsung dari penerbit dan menjual ke pasaran.

Imam Samudra menyatakan bahwa sejak diberlakukannya Jihad sebagai fardlu ain pada masa Rasulullah, maka seluruh umat Islam masuk dalam Ahluts-Tsughur. Selanjutnya, Samudra memberi contoh nama-nama Ulama Ahluts-Tsughur yang "tidak ada seorangpun dari [mereka] yang tidak pernah mengangkat senjata dan berjihad melawan kaum kafir" (Samudra, 2004: 69). Mereka adalah seluruh Imam Madzhab, Ibnu Taimiyah dan muridnya Ibnu Qayyim Al-Jauziyyah, kemudian pada abad berikutnya Shalahuddin Al Ayyubi, Umar Mukhtar, disusul generasi abad 20, Syaikh Dr. Abdullah Azzam (w. 1987 di Pakistan), Syaikh Aiman Az- Zawahiri, Syaikh Sulaiman Abu Ghaits, Syaikh Mullah Omar, Syaikh Usamah Bin Laden, juga di Pakistan ada Syaikh Mir Hamzah dan Maulana Mansoor (Samudra, 2004: 6970).

Buku pertama yang menyentuh hati Imam Samudra adalah karya Dr. Abdullah Azzam, Ayatur Rahman fie Jihadi Afghanistan (Tanda-tanda Kekuasaan Allah dalam Jihad di Afghanistan). Samudra menyatakan:

"Mereka yang sempat membaca buku ini, Insya Allah akan tergerak hatinya untuk berjihad mengangkat senjata ke Afghanistan... Lebih dari sekali buku itu kubaca, dan selesai membacanya selalu Aku berdo'a semoga Allah menyampaikanku ke Afghani- 
stan, negeri para syuhada, negeri para penghuni syurga" (Samudra, 2004: 41).

Ketika itu umur Imam Samudra 16 tahun, masih siswa kelas 3 SMP Negeri 4 Serang, Banten. Selanjutnya Samudra menyatakan: "sejak mengenal 'buku ajaib' itu, aku tak pernah berhenti berdo'a agar Allah menggabungkanku dengan para mujahidin dan menjadikanku salah satu syuhada" (Samudra, 2004: 42). Imam Samudra adalah salah satu siswa brilian. Sejak SD hingga SMP hampir selalu mendapat juara di setiap kelasnya. Bahkan ditingkat Kabupaten Serang, Samudra kecil salah satu terbaik dalam beberapa lomba. Pada saat lulus SD, hasil evaluasi belajar akhir nomor dua terbaik se Kabupaten.

Imam Samudra juga mendapat inspirasi dari seorang Jihadis dari Timur Tengah, Syaikh Abu Ibrahim Al-Mishri tentang tujuan Jihad, yaitu

(1) menghancurkan penghalang-penghalang yang menyekat tersebarnya dien (agama) ini ke seluruh penjuru dunia...(2) menolak kezaliman dan mengukuhkan yang haq sekaligus mencegah kaum Muslimin dari kerusakan dan kehancuran (akibat kezhaliman kaum kafir)... (3) menjaga eksistensi dan kemuliaan kaum Muslimin, serta menolong mustadh'afin (orang-orang yang tertindas)... (4) menghinakan musuh-musuh Allah, menggentarkan mereka, dan mencegah keganasan mereka, (5) untuk menyaring-bersihkan orang-orang beriman, membinasakan orang-orang kafir, dan memilih para syuhada'... (6) untuk mengukuhkan kekuasaan di muka bumi demi tegaknya syari'at yang adil dan terlaksananya keperluan hidup dibawah naungan aturan Allah... (7) untuk memperoleh karunia lain yang diperlukan oleh manusia yang dijanjikan Allah... (8) demi memperoleh ridla Alllah Ta'ala." (Samudra, 2009: 87).

Imam Samudra banyak mengutip pandangan Aiman al-Zawahiri, dan menyatakan kagum atas intelektualisme dan pengalaman jihad al-Zawahiri.

Aiman al-Zawahiri lahir pada 19 Juni 1951 di Maadi, Mesir. Memiliki nama sejak lahir Aiman Muhammad Rabayah al-Zawahiri. Al-Zawahiri memiliki beberapa nama yaitu Abu Muhammad, Abu
Fatima, Muhammad Ibrahim, Abu Abdallah, Abu alMu'iz, Dokter, Dosen, Nur, Ustaz, Abu Muhammad Nur al-Din, Abdul Muaz (Abdul Moez).

Al Zawahiri berasal dari keluarga kaya, seorang dokter dan ilmuwan. Alumni Universitas Kairo pada 1974 dan mendapatkan gelar master Kedokteran spesialis bedah pada 1978. Al-Zawahiri menguasai Bahasa Arab, Inggris dan Perancis. Setahun setelah resmi menjadi ahli bedah, al Zawahiri memilih bergabung dengan Mujahidin di Afghanistan melawan Uni Soviet. Di Afghanistan pula, al Zawahiri bertemu Osama bin Laden, pemimpin Al Qaidah. Pada 1998, Al Zawahiri secara resmi menggabungkan kelompok Jihad Islam Mesir kedalam Al Qaidah, dengan melakukan pernyataan bersama. Pada 2001, Al Zawahiri menerbitkan buku Knights Under the Prophet's Banner. Al-Zawahiri sering disebut sebagai "the real brains" atau otak gerakan Al-Qaidah.

Ali Ghufran (Mukhlas) dalam risalah "Maktabah Kita” memberikan komentarnya setelah membaca tuntas kitab karya Syekh Ayman, At Tabriah. Menurut Ghufran, inti kandungan kitab karya Dr. Fadl yang ditulisnya dalam penjara Mesir itu adalah,

1. Memperbaharui dan memperhebat kritikannya terhadap operasi-operasi jihad yang pernah ditulis dalam kitab Al-Jamie, dan kali ini sasaran utamanya adalah Al Qaidah sebagai tandzim atau jama'ah jihad, sedang secara individu adalah Asy Syekh Ayman dan Asy Syekh Usamah bin Ladin. (At Tabriah, Muqaddimah hal. 3)

2. Berusaha menghentikan operasi-operasi jihad dengan alasan kaum Muslimin (mujahidin) lemah dan tidak berdaya dan dengan alasan tidak terpenuhinya penopang-penopang jihad.

3. Menunjukkan kepada ummat keraguannya terhadap pendapat-pendapatnya dan fatwa-fatwanya yang ditulis selama ini di dalam kitab-kitabnya, dan seperti memberi isyarat agar tidak diikuti, khususnya dalam masalah yang berhubungan dengan jihad dan operasi jihad yang tidak sejalan dengan "Watsiqah Tarsyid”. (Menggugat Al Qaidah) (Prince of Jihad, 2010).

Beberapa Ulama yang menurut Ali Ghufran layak 
untuk diikuti, yaitu: (1) Al-Imam Al-Bukhari (w. 256 H.), (2) Al-Imam Abul Fida' Al-Hafidz Ibnu Katsir (w. 774), (3) Al-Imam Yahya bin Syaraf bin Hasan bin Husain bin Jam'ah bin Hazzam, Muhyidin Abu Zakaria an-Nawawi (631-676 H), (4) Al-Imam Abdul Wahid bin Adam Ath-Thawawisi, (5) Al-Imam Abu Zakaria Ahmad bin Ibrahim Muhammad (w 814 H.), (6) Asy-syaikh Abdullah Azzam, (7) al-Ustadz Muhammad Najib Al-Muthii (Ghufran, 2009: 74-79).

Dr. Abdullah Azzam adalah mentor (dosen pembimbing) Usamah Bin Laden ketika masih kuliah di Saudi Arabia. Adalah Dr. Azzam yang memberi inspirasi Usamah Bin Laden dan para pelajar Arab untuk berjihad ke Afghanistan. Selain Dr. Azzam, sebelumnya ada Sayyid Qutb dan Abd. al-Salam Faraj. Qutb, Faraj dan Azzam adalah ilmuwan dan penulis radikal sunni yang telah menginspirasi kaum muda Muslim di Timur Tengah dan wilayah lain untuk berjihad. Buku Faraj, Al-Faridah al-Ghaibah (Tugas yang Terlupakan) menginspirasi aktivis Muslim tahun 1980an untuk bergabung dengan kelompok jihad. Menurut Faraj "Jihad tidak hanya komitmen pribadi tetapi juga [bersungguh-sungguh] melawan musuhmusuh Islam...siapa yang berpartisipasi dalam jihad yang benar maka akan mendapatkan imbalan pada level tertinggi di Syurga. Jihad harus terus ditegakkan hingga Islam bisa menguasai seluruh dunia" (Ali dan Post, 2008: 9).

Selain para ulama dan tokoh Mujahidin yang menginspirasi Imam Samudra, Ali Ghufran dan Amrozi, mereka juga mendapat asupan tenaga dari mimpi-mimpi. Ali Ghufran dan Amrozi menulis secara rinci mimpi-mimpi mereka yang terkait dengan Jihad, dan pengalaman mereka ketika dipenjara pasca Bom Bali. Juga mimpi dan ucapan Imam Samudra, yang menjadi kenyataan. Abu Jibril menggambarkan bagaimana mimpi Samudra, Ghufron dan Amrozi. Menurut Jibril:

"Mereka telah bertemu dengan Rasulullah dalam mimpi yang sangat indah, memperoleh tarbiyah asykari, dan juga mendapatkan tausiyah Baginda [Nabi]. Keberanian, kehebatan dan ketabahan yang dimiliki sulit dicari tandingannya...Ditambah lagi dengan cerita akhi Mukhlas dan Amrozi yang menceritakan pertemuannya dengan bidadari yang cantik bermata jeli dalam mimpinya" (Jibriel, 2009: 14).

Pemikiran Jihadis menjadi propaganda utama untuk melegitimasi aksi Jihad dan teror. Aksi AlQaidah dan IS didukung legitimasi ulama dalam serial pemboman dibanyak negara. Sementara tulisan Jihadis Indonesia juga menjadi instrumen penting dalam perkembangan aksi terorisme di Indonesia dan Asia Tenggara. Pemikiran Abu Bakar Ba'asyir, Aman Abdurrahman dan pelaku pengeboman di Bali dan Kedutaan Australia bisa diakses oleh jihadis jaringan melayu. Karena itu, ulama jihadis Indonesia bisa memengaruhi perkembangan dakwah yang berbasis salafi-jihadi di Asia Tenggara.

Pasca Bom Bali 2002 dan 2005, jaringan Al Qaedah di Asia Tenggara terungkap setelah adanya pertukaran informasi intelijen antar negara-negara anggota ASEAN. Pengalaman menangani jaringan Al Qaedah ini menjadi pelajaran penting bagi Polisi dan pemerintah dalam menghadapi jaringan ISIS dan mengantisipasi ancaman keamanan sepulangnya jihadis ISIS dan JN dari Suriah dan Irak ke Asia Tenggara. Sekitar 800-1000 jihadis asal Asia Tenggara berafiliasi dengan ISIS berada di Suriah dan Irak yang kini terdesak akibat operasi gabungan Barat, serta tekanan yang terus dilakukan oleh Pemerintah Bashar Al-Asad yang didukung Rusia dan Iran.

\section{STRATEGI ISIS DI ASIA TENGGARA}

ISIS Asia Tenggara merupakan bagian dari ISIS dunia. Beberapa penerbitan resmi ISIS antara lain Dabiq diterjemahkan kedalam Bahasa Indonesia untuk konsumsi komunitas ISIS di Asia Tenggara. Jaringan transnasional Asia Tenggara ISIS dan Timur Tengah khsusnya di Suriah dan Iraq menjadi elemen penting pola dan dinamika pergerakan aksi ISIS bagaimana mereka mengembangkan jaringannya dan melakukan aksi penyerangan. Sebelum ISIS menerbitkan majalah dan publikasi lain, elit spiritual ISIS juga sudah menulis melalui buku dan media online yang sangat berpengaruh atas radikalisasi Muslim di Asia Tenggara. 
Hal ini terus berlanjut dengan pemikiran yang lebih taktis. Beberapa aksi terorisme di Indonesia dan Malaysia yang dilakukan oleh ISIS diawali melalui jaringan Suriah-Irak-Asia Tenggara.

ISIS jaringan Asia Tenggara berkembang melalui dua strategi. Pertama, Katibah Nusantara (KN) organisasi yang dibentuk oleh kombatan ISIS asal Indonesia, Indonesia dan Filipina di Suriah dan Irak menjadi hub yang menyatukan kombatan berbahasa Melayu. KN tidak hanya aktif terlibat pertarungan tetapi juga membantu publikasi versi Bahasa Indonesia pada majalah, artikel dan pernyataan yang berasal dari pusat informasi ISIS di Suriah. KN juga aktif dalam memberi informasi secara langsung melalui sosial media dan bloging yang dibentuk oleh pasukan media ISIS asal Asia Tenggara. Kedua, strategi melalui penguatan jaringan, interaksi dan aksi dengan kelompok-kelompok jihadis di Indonesia, Malaysia dan Filipina. Home-grown terorisme ini menjadi ancaman langsung atas pergerakan dan aktis terorisme oleh jaringan dan individu yang berafiliasi dengan ISIS. Hubungan saling mendukung antar organisasi teroris dalam afiliasi ISIS sangat nampak. Misalnya dalam pernyataan dan tulisan Aman Abdurrahman, Santoso dan Ba'asyir mendukung jihad di Filipina Selatan melawan pemerintah Thoghut, dan sebaliknya Abu Sayaf juga mendukung aksi ISIS Indonesia dalam melakukan aksi teror.

Aman Abdurrahman menulis artikel dan buku yang dijual online melalui blog pribadi, millahibrahim.blogspot.com, yang pada saat menyelesaikan tulisan ini September 2015 blog ini tidak bisa diakses. Tetapi Aman menikmati kebebasan selama bertahun-tahun dalam menyampaikan tulisannya melalui blog tersebut. Aman menginspirasi penulis-penulis ISIS lainnya. Diantaranya Bahrun Naim yang memberi manual aksi terorisme melalui web yang dikendalikan dari luar negeri. Pasca serangan Thamrin pada Januari 2016, Bahrun Naim memberi komentar "Selamat" bagi para pelaku penyerangan. Bahrun Naim telah menulis peringatan beberapa bulan sebelum serangan Thamrin bahwa akan ada operasi "Konser Jakarta" yang mendapat inspirasi "Konser
Paris".

Muhammad Bahrunnaim Anggin alias Na'im lahir di Pekalongan, pada 6 September 1983. Naim bergabung dengan JAT pada September 2008. Pertama, Naim masuk dalam sel Abdullah Sonata, kemudian mengikuti Pelatihan Militer di Jalin Janto, Aceh pada 2010. Na'im di penjara di Surakarta pada 9 November 2010 dengan tuduhan menyimpan senjata dan amunisi. Na'im dipenjara 2 tahun, 6 bulan, dan pada 2012 berakhir masa tahanannya. Dua tahun kemudian, Na'im bergabung dengan ISIS dan berangkat ke Suriah. Secara rutin Na'im menulis pengalaman Jihad di blog pribadinya bahrunnaim.com; bahrunnaim.site.

Ba'asyir dan Aman merupakan ikon penting dalam perkembangan ISIS di Indonesia, dan memiliki pengaruh di Asia Tenggara. Banyak pelajar dan pemuda yang berbai'at kepada Al- Baghdadi karena pengaruh Ba'asyir dan Aman. Ba'asyir dan Aman memengaruhi jaringan Jamaah Ansharut Daulah (JAD) yang menjadi organisasi lokal Indonesia yang terkait dengan ISIS di Suriah. Dalam jaringan ini Bahrumsyah, Bahrun Naim dan Salim Mubarak Attamimi memiliki peran penting menjaga soliditas jihadis Indonesia dan Asia Tenggara dalam jaringan Katibah Nusantara di Suriah.

Pada level regional, Ba'asyir dan Aman memiliki peran strategis bagi pengembangan ideologi ISIS di Asia Tenggara. Daulah Islam Malizia (DMI), salah satu sel ISIS di Malaysia dan bekerja sama dengan Kumpulan Arakan Daulah Islamiyyah bermaksud mendirikan negara Islam di Asia Tenggara. Polisi Malaysia menemukan DIM melanjutkan ideologi yang sudah berjalan di Malaysia yaitu Jama'ah Islamiyah, Darul Islam dan Kumpulan Mujahidin Malaysia. DIM menggunakan buku-buku dan tulisan Ba'asyir dan Aman sebagai "reading materials" dalam kajian rutin rekrutmen, konsolidasi dan pergerakan organisasi dalam lingkaran DIM (El-Muhammady, 2016: 111). Antara Februari 2013 hingga 2015, Polisi Malaysia telah menahan 107 orang yang terlibat dalam gerakan terorisme. Mayoritas diantara mereka (80 orang) berumur antara 18-40 tahun. Hanya 15 orang berumur lebih dari 40 tahun. Kurang dari 18 tahun 
berjumlah 12 orang. Ini menunjukkan target sasaran ISIS dan gerakan radikalisme mengarah ke kelompok muda. Terutama akibat interaksi melalui sosial media (El-Muhammady, 2016: 111). Thomas Koruth Samuel menyatakan bahwa para komandan jihadis di Asia Tenggara menempati posisi tinggi pada usia 20an, setelah bertahun-tahun bergabung dalam lingkungan pendidikan, latihan perang dan bahkan pertarungan pada usia belasan tahun. Abdurrajak Janjalani membentuk Kelompok Abu Sayaf pada usia 26 tahun, kemudian digantikan oleh Khadafy Janjalani (usia 22 tahun) setelah Abdurrajak terbunuh pada 1998. Amir Abu Sayaf, Yasser Igasan, mulai ikut ASG pada usia 21 tahun. Kelompok radikal lainnnya di Filipina, Gerakan Rajah Solaiman (RSM, Rajah Solaiman Movement) yang berasal dari perkumpulan siswa dan guru di madrasah di Luzon, didirikan oleh Ahmad Santos. Santos mulai terlibat pada usia 21 tahun. RSM melakukan 14 pemboman superferry pada 27 Februari 2004 (Samuel, 2012: 6-7). Bagi JI, ISIS dan kelompok teroris lainnya individu dan kelompok muda merupakan target paling mudah mendapat pengaruh karena masa aktualisasi diri dan pola interaksi yang memengaruhi pertumbuhan ideologi mereka. Dalam penelitian yang dilakukan pada 2007, salah seorang responden yang merupakan staf pengajar di Pondok Al Mukmin Ngruki mengakui bahwa siswa dan alumni Al Mukmin Ngruki lebih banyak dipengaruhi bahan bacaan dan interaksi dari luar pondok yang membentuk karakter jihad mereka (Sholeh, 2007). Salah satu sel yang dibentuk gabungan alumni dan siswa Al Mukmin Ngruki yang menyerang pos Polisi di Solo pada 2014 melakukan kajian kelompok sendiri dengan bacaan dari artikel dan buku Aman Abdurrahman yang mudah didownload dari blog Aman tanpa mengundang guru-guru mereka secara langsung. Rekrutmen, pengembangan jaringan dan aksi ISIS di Asia Tenggara banyak dilakukan melalui kelompok muda.

\section{KESIMPULAN}

Pemikiran, pengalaman dalam konflik dan perang serta respon pemerintah dan masyarakat sipil memengaruhi dinamika perkembangan dan ancaman terorisme di Asia Tenggara. Pemikiran elit jihadis baik dari Suriah dan Irak, dan khususnya di Asia Tenggara akan terus menumbuhkan ideologi radikal jihadis. Pemikiran ini menjadi alat strategi dan taktik gerakan yang berafiliasi dengan JI dan ISIS di wilayah regional dan internasional.

Pemikiran jihad Abu Bakar Ba'asyir dan Aman Abdurrahman serta penulis jihadis lain di Indonesia dan Asia Tenggara sangat memengaruhi dinamika radikalisasi regional. Buku, artikel, pledoi, pidato dan khutbah yang mereka tulis tidak hanya disalin melalui sosial media tetapi juga dibukukan secara profesional melalui penerbitan yang dikelola oleh kelompok jihadis. Blogging, media online dan media sosial yang memuat tulisan jihadis Asia Tenggara menginspirasi pergerakan jihad ditingkat regional. Jaringan transnasional ISIS yang aktif dan masif dilakukan dengan memanfaatkan media sosial menjadi tantangan serius tidak hanya dalam menghentikan serangkaian teror tetapi lebih penting lagi membendung tekanan radikalisasi yang menyasar kelompok muda Muslim di Asia Tenggara.

Tantangan bagi pemerintah dan masyarakat sipil adalah semakin berat kebijakan kontra terorisme yang selama ini masih didominasi oleh negara. Masyarakat sipil, khususnya Nahdlatul Ulama dan Muhammadiyah masih menjadi silent majority yang membutuhkan kerjasama komprehensif bersama pemerintah di Indonesia dan negara serta masyarakat sipil di Asia Tenggara. Badan Nasional Penanggulangan Terorisme (BNPT) mestinya menjalankan fungsi koordinatif, dan tidak menjalankan program sendiri. Keterbatasan sumber BNPT dalam kontra terorisme terutama dalam mengimbangi progresivitas karya tulis jihadis perlu merangkul lebih luas ulama, sarjana dan masyarakat sipil. Demikian juga pada level regional, pada ASEAN Summit 6-8 September 2016 di Laos semua kepala negara sepakat bahwa terorisme menjadi ancaman bersama. Semakin banyaknya self-radicalisation dan lone wolf banyak dipengaruhi media online dan tulisan jihadis. Aksi pemboman Gereja di Medan pada 28 Agustus 2016 juga salah satu lone wolf yang 
terinspirasi oleh karya tulis jihadis.

Gerakan strategis dan taktis JI dan ISIS dilakukan melalui kerja kolektif yang cukup lama dan melibatkan gerakan transnasional baik di Asia Tenggara maupun di Afghanistan, Suriah dan Irak. Karena itu, kerjasama yang solid dan komprehensif antar negara-negara dan masyarakat sipil di Asia Tenggara, Timur Tengah, Eropa dan negara dunia menjadi sangat penting tidak hanya menghentikan aksi-aksi teroris tetapi membendung derasnya pengaruh radikal jihadisme yang dikembagkan oleh para veteran Afghanistan, Mindanao, Suriah dan Irak.

Pemikiran yang ditulis melalui penerbit jaringan JI dan ISIS serta tulisan melalui blog dan media online termasuk media sosial semakin menjadi tantangan negara dan masyarakat sipil. Keamanan virtual dan kontra narasi dibutuhkan kerja bersama dan kolektif negara dan masyarakat sipil. BNPT tidak bisa melakukan sendiri bagaimana melawan pemikiran Aman Abdurrahman melalui media online yang mereka kembangkan, tetapi lebih penting lagi peran sarjana, ulama dan intelektual di Nahdlatul Ulama, Muhammadiyah, MUI, juga lembaga keagamaan di Singapura, Malaysia, Filipina, Thailand dan negaranegara dunia agar bekerjasama lebih erat dan konsisten untuk mengatasi terutama menjelang veteran Suriah dan Irak yang dalam beberapa tahun akan menjadi ancaman keamanan serius di kawasan Asia Tenggara dan dunia.

\section{REFERENSI}

\section{BUKU DAN MEDIA}

Abdurrahman, Abu Sulaiman Aman. 2013. Mutiara dari Balik Penjara Penyejuk Orang yang Beriman. Banten: P-TA Press.

Abdurrahman, Abu Sulaiman Aman. 2015. Seri Materi Tauhid for the Greatest Happiness, Rilisan ke II 1 Ramadhan 1436 H/ 18 Juni, millahibrahim.wordpress.com.

Ali, Farhana dan Jerrold Post. 2008. "The History and Evolution of Martyrdom in the Service of Defensive Jihad: An Analysis of Suicide Bombers in Current Conflicts", Social Research, 1 Juni.

Ba'asyir, Abu Bakar. 2013. "Kata Pengantar dari Ustadz Abu Bakar Ba'asyir," dalam Abu Sulaiman Aman Abdurrahman, Mutiara dari Balik Penjara Penyejuk Orang yang Beriman. Banten: P-TA Press.

Ba'asyir, Abu Bakar. 2003. "Renungan dari Penjara," dalam Irfan Suryahadi Awwas (ed.), Dakwah dan Jihad Abu Bakar Ba'asyir. Yogjakarta: Wihdah Press.
Damanik, Caroline. 2014. "Kisah Wildan di ISIS di mulai dari Sekolah di Mesir," Kompas, 14 Agustus.

El-Muhammady, Ahmad. 2016. "Countering the Threats of Daesh in Malaysia," dalam Beatrice Gorawantschy, Rohan Gunaratna, Megha Sarmah dan Patrick Rueppel (ed.), Countering Daesh Extremism Europe and Asian Responses, Panorama Insights into Asian and European Affairs, 02/ 2016, Singapura: Konrad Aderauer Stiftung dan S. Rajaratnam School of International Studies.

Ghufran, Ali. 2009. Mimpi Suci diBalik Jeruji Besi Hikmah Mimpi yang Benar dan Baik, Jakarta: Ar-Rahmah Media.

Horgan, John. 2008. “Deradicalization or Disengagement? A Process in Need of Clarity and a Counterterrorism Initiative on Need of Evaluation," Perspectives on Terrorism, Volume II, Issue 4, Februari.

Samudra, Imam. 2009. Jika Masih ada yang Mempertanyakan Jihadku [sebuah catatan terakhir dari Nusakambangan]. Solo: Kafilah Syuhada' Media Centre.

Jones, Sidney. 2015. "ISIS in Southeast Asia: Problems Now and Later," Private Discussion, Center for East Asia Policy Studies, Brookings Institution, Somers Room, 5 Juni, Washington DC. Diakses 6 November 2016 dari https://www.brookings.edu/wp-content/ uploads/2015/06/20150606_sidney_jones_transcript.pdf.

Jibriel, Abu Muhammad. 2009. "Kata Pengantar", dalam Amrozi bin Nurhasyim, Senyum Terakhir Sang Mujahid Catatan Kehidupan Seorang Amrozi, Jakarta: Ar-Rahmah Media.

Samuel, Thomas Koruth. 2012. Reaching the Youth: Countering the Terrorist Narrative, Kuala Lumpur: Southeast Asia Regional Centre for Counter-Terrorism.

Magouirk, Justin dan Scott Atran. 2008. "Jema'ah Islamiyah's radical madrasah networks," Dynamics of Asymetric Conflict, Vol. 1, No. 1, Maret.

Prince of Jihad. 2010. "Kritik Buku Menggugat AlQaidah: Merasionalisasi Jihad Dunia Dari Penjara Mesir", http:// arrahmah.com/index.php/blog/read/4713/kritik-buku-menggugatal-qaidah-merasionalisasi-jihad-dunia\#ixzz14kOi4J9k, diakses 9 November 2010

Sholeh, Badrus. 2016. "Daesh in Europe and Southeast Asia: An Indonesian Perspective," dalam Beatrice Gorawantschy, Rohan Gunaratna, Megha Sarmah dan Patrick Rueppel (ed.), Countering Daesh Extremism Europe and Asian Responses, Panorama Insights into Asian and European Affairs, 02/ 2016, Singapura: Konrad Aderauer Stiftung dan S. Rajaratnam School of International Studies.

Sholeh, Badrus. 2013. Catatan Kunjungan di Penjara Nusa Kambangan. Agustus.

Sholeh, Badrus (ed.). 2007. Tradisi Damai Komunitas Pesantren Jakarta: LP3ES.

Singh, Jasminder. 2015. "Katibah Nusantara: Islamic State's Malay Archipelago Combat Unit," RSIS Commentary, No. 126, 26 Mei. Diakses 6 November 2016 dari https://www.rsis.edu.sg/wp-content/ uploads/2015/05/CO15126.pdf.

Sukirno, Bambang (ed.). 2004. "Pengantar Editor", dalam Imam Samudra, Aku Melawan Teroris. Solo: Jazera. 
Asad, wawancara dengan penulis di Surabaya, 6 September 2014.

Bambang, wawancara dengan penulis di penjara Porong, 3 September 2016.

Fachry, M., wawancara dengan penulis di Jakarta, 10 November 2010

Farihin Aka Yasir, wawancara dengan penulis di Jakarta, Agustus 2015. 